\title{
Evaluation of Surface Water Quality on Spatiotemporal Gradient Using Multivariate Statistical Techniques: A Case Study of River Chenab, Pakistan
}

\author{
Firdaus Kausar ${ }^{1 *}$, Abdul Qadir'1, Sajid Rashid Ahmad ${ }^{1}$, Mujtaba Baqar ${ }^{2}$ \\ ${ }^{1}$ College of Earth and Environmental Sciences, University of the Punjab, New Campus, Lahore, Pakistan \\ ${ }^{2}$ Sustainable Development Study Centre, Government College University, Lahore, Pakistan
}

Received: 26 January 2018

Accepted: 5 July 2018

\begin{abstract}
The Chenab River is experiencing deteriorating water quality due to ill-planned industrialization, population pressure, extensive agriculture, water diversion and rapid urbanization. Our study was designed to highlight the spatiotemporal variation in the water quality of the Chenab and identify potential pollution sources using multivariate analyses viz cluster analysis, discriminant analysis, principal component analysis and factor analysis. Water samples were collected from nine sampling sites along the Chenab from 2012 to 2014 during dry and wet seasons. Cluster analysis identified three zones, i.e., least stressed zone (LSZ), moderately stressed zone (MSZ) and highly stressed zone (HSZ). The discriminant analysis differentiated seven parameters $\left(\mathrm{COD}, \mathrm{Cl}, \mathrm{SO}_{4}, \mathrm{~K}, \mathrm{Cu}, \mathrm{Cd}\right.$ and $\mathrm{Pb}$ ) and five parameters (TDS, $\mathrm{Cl}, \mathrm{S}, \mathrm{F}$ and $\mathrm{Ca}$ ) as most significant on spatial and temporal bases, respectively. The untreated industrial and domestic wastewater, atmospheric deposition and surface runoff containing heavy metals and fertilizer along with a decrease in dilution factor due to the diversion of the water through link canals were identified as the major factors causing water quality deterioration. Therefore, the results imply that a comprehensive water management plan and implementation of environmental laws are urgently needed to protect Chenab water quality.
\end{abstract}

Keywords: Chenab River, anthropogenic stress, spatiotemporal variation, multivariate statistical techniques

\section{Introduction}

Rivers are essential for life as they serve creatures with ample freshwater supply. Although rivers represent

*e-mail: firdaus.chemist@gmail.com merely $0.0001 \%$ of the planet's total water fraction, they carry water and nutrients to the biosphere [1]. In recent years, one of the greatest environmental concerns for developing countries is associated with the deterioration of riverine water quality for the reason that the rivers are considered to be an easy dumping ground for wastewater in developing countries [2]. At the same 
time, as the human population outbursts in developing countries the water demand increases significantly, which subsequently upsurges its wastewater production [3]. The wastewater load to rivers would accelerate further with increased urbanization situation. The pollution of rivers and their tributaries is worst near urban stretches due to enormous amounts of untreated wastewater discharged by urban activities (industrial, commercial and domestic), rendering the water unfit for different uses, including drinking, domestic, recreational, agriculture and aquatic life [4].

Like other developing countries of the region, in Pakistan untreated or partially treated domestic and industrial effluents are being drained into rivers [5-7]. These effluents may also contain toxic substances that exert adverse effects on the riverine ecosystem along with the human food chain [8]. In context to Pakistan, the contribution of contamination from natural factors is negligible as compared to anthropogenic activities [5]. Among anthropogenic activities, agricultural runoff also significantly influences the water quality of the rivers $[6,9]$. Pakistan is an agrarian country whereby its rivers are considered to be the backbone of the country's agrobased economy [3]. The Chenab, the second largest river of Pakistan, plays a significant role in this regard as its water is being used for irrigation, livestock and aquaculture [10]. The catchment area of the Chenab covers the most productive agricultural region of Pakistan, where uncontrolled use of agro-chemicals exerts enormous stress on the Chenab's water quality [11]. Furthermore, the river passes through industrial and densely populated cities of Pakistan, which consequently discharge a significant amount of wastewater related to anthropogenic discharge into the river's channel [12].

For sustainable and effective management of pollution load in the Chenab, it is essential to monitor and develop a water quality database. Although several studies have been conducted in the past to highlight water quality deterioration $[5,10,13]$, the data matrix is sometimes too extensive and complicated that it is not easy to comprehend [14]. For this reason, multivariate statistical techniques have been used. The current study aims to highlight the spatial and temporal variations in Chenab water quality on the basis of selected physiochemical parameters. Statistical techniques were utilized to identify the sources and pollution hotspots that would assist in managing these vulnerable river segments more effectively. To the best of our knowledge, this is a pioneer study of its type from the study area that would contribute expediently in future global freshwater studies.

\section{Materials and Methods}

\section{Study Area and Sampling Strategy}

The Chenab is a transboundary river originating from the snowcapped peaks of the Himalayas in
Himachal Paresh, India and enters into Pakistan a few kilometers upstream to the Marala Barrage $\left(74^{\circ} 29^{\prime} \mathrm{E}\right.$ and $32^{\circ} 40^{\prime} \mathrm{N}$ ) in Sialkot. The study area contains sub-tropical climatic conditions that vary from subhumid to semi-arid in upstream, semi-arid to arid in midstream and arid in downstream areas of the Chenab. The river is surrounded by one of the most intensively cultivated regions, encompassing Rachna Doab and Jech Doab with Kharif and Rabi cultivation patterns during summer-monsoon season and drier-winter season, respectively. The intensified cultivation and livestock in the region makes agriculture a major attribute to determine the socio-economic state of Pakistan. In Pakistan, five barrages (Marala, Khanki, Qadirabad, Trimmu and Punjnad) have been constructed on the river to divert the water through link canals to effectively irrigate crops.

Nine sampling sites (Fig. 1) were selected on the river based on the anthropogenic stress and their accessibility. A preliminary survey was conducted prior to research sampling strategy design to collect the information about potential pollution sources along the river, consider land accessibility and mark the coordinates of the sampling sites for a sampling program using a GARMIN eTrax 20 GPS device. The sample collection from the recorded sampling sites was conducted during two seasons, i.e., dry (April to May) and wet (July to September) seasons for a period of three years: 2012-2014.

\section{Sampling and Analysis of Water Samples}

Water sampling was carried out by composite sampling technique from the point of turbulent flow of selected sampling sites, at a depth of $30 \mathrm{~cm}$ during daytime, between 10:00 and 16:00. Water samples were collected, sealed, labeled, preserved and transported in accordance with the protocols of the American Public Health Association (APHA) [15]. All the samples were kept in an ice-box containing wet ice and transported to a wastewater laboratory of the Environmental Protection Department and Irrigation Department Lab, where most of the analysis was performed while heavy metals analysis were conducted at the College of Earth and Environmental Sciences.

The field parameters, i.e., temperature $\left({ }^{\circ} \mathrm{C}\right), \mathrm{pH}$, dissolved oxygen (DO) and electrical conductivity (EC), were monitored on-field using HANNA H198107, Milwaukee-MW600 and HANNA H198303 instruments, respectively. Whereas the determination of the physiochemical parameters in the laboratory were based on APHA's standard procedures [15], biological oxygen demand (BOD) was determined by method No. 5210-B, total suspended solids (TSS) by method No. 2540-D, total dissolved solids (TDS) by method No. 2540-C, chloride $\left(\mathrm{Cl}^{-1}\right)$ by argentometry using method No. 4500-B, sulphate $\left(\mathrm{SO}_{4}^{-2}\right)$ by method No. 4500-D, potassium (K) and sodium (Na) using a Jenway PFP7 flame photometer by method Nos. 


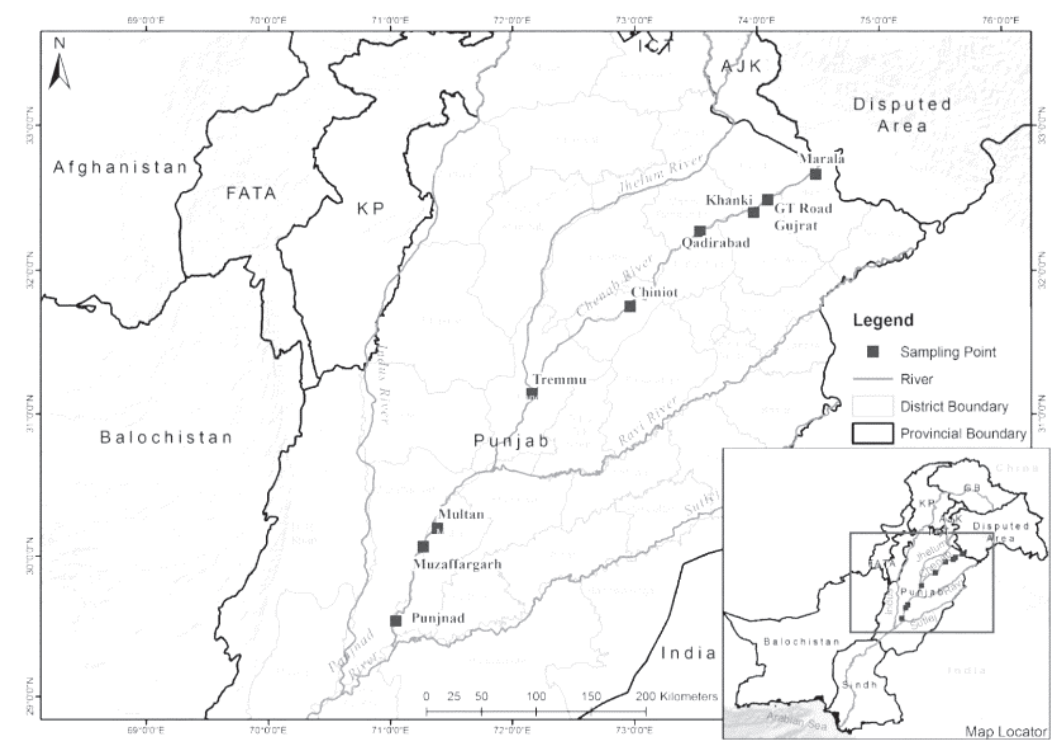

Fig. 1. Map representing sampling sites along the Chenab River in Pakistan.

3500-K-B and 3500-Na-B, calcium (Ca) by complexmetric titration method No. 3500-Ca-B and chemical oxygen demand (COD) was analyzed through method No. K0102 of Japanese Industrial Standards (1998). For heavy metals, e.g., iron $(\mathrm{Fe})$, lead $(\mathrm{Pb})$, chromium
$(\mathrm{Cr})$, copper $(\mathrm{Cu})$ and cadmium $(\mathrm{Cd})$ analysis, samples were prepared through acid digestion and analyzed using a Perkin Elmer AAnalyst 800 atomic absorption spectrometer.

Table 1. Comparison of water quality data from River Chenab, Pakistan with the standards from the countries of the region.

\begin{tabular}{|c|c|c|c|c|c|c|c|c|c|c|c|c|}
\hline \multirow{2}{*}{ Parameter } & \multirow{2}{*}{ Mean \pm SD } & \multirow{2}{*}{ Range } & \multicolumn{2}{|c|}{ Class 1} & \multicolumn{2}{|c|}{ Class 2} & \multicolumn{2}{|c|}{ Class 3} & \multicolumn{2}{|c|}{ Class 4} & \multicolumn{2}{|c|}{ Class 5} \\
\hline & & & China $^{a}$ & India $^{\mathrm{b}}$ & China $^{\mathrm{a}}$ & India $^{b}$ & China $^{\mathrm{a}}$ & India $^{b}$ & China $^{a}$ & India $^{b}$ & China $^{a}$ & India $^{\mathrm{b}}$ \\
\hline $\mathrm{pH}$ & $7.822 \pm 0.355$ & $7.02-8.64$ & $6-9$ & $6.5-8.5$ & $6-9$ & $6.5-8.5$ & 6- 9 & $6.5-8.5$ & 6- 9 & $6.5-8.5$ & 6- 9 & $6.5-8.5$ \\
\hline DO & $8.897 \pm 0.929$ & $7.5-11$ & 7.5 & 6 & 6 & 5 & 5 & 4 & 3 & 4 & 2 & \\
\hline TDS & $210.703 \pm 95.325$ & $110-550$ & & 500 & & & & 1500 & & & & 2100 \\
\hline COD & $15.188 \pm 8.049$ & $4.0-48$ & 15 & & 15 & & 20 & & 20 & & 25 & \\
\hline BOD & $6.113 \pm 3.483$ & $1.6-24$ & 3 & 2 & 3 & 3 & 4 & 3 & 6 & & 10 & \\
\hline $\mathrm{Cl}$ & $73.314 \pm 55.89$ & $10-220$ & 250 & 250 & 250 & & 250 & 600 & 250 & & 250 & \\
\hline $\mathrm{SO}_{4}$ & $55.074 \pm 43.941$ & $18-240$ & 250 & 400 & & & & 400 & & & & \\
\hline $\mathrm{F}$ & $0.376 \pm 0.24$ & $0.15-1.02$ & 1 & 1.5 & 1 & 1.5 & 1 & 1.5 & 1.5 & & 1.5 & \\
\hline $\mathrm{Ca}$ & $30.601 \pm 10.21$ & $12-65$ & & 75 & & & & & & & & \\
\hline $\mathrm{Cd}$ & $0.0655 \pm 0.074$ & $0.001-0.329$ & 0.001 & & 0.005 & & & 0.01 & & & & \\
\hline $\mathrm{Pb}$ & $0.195 \pm 0.152$ & $0.002-0.989$ & 0.01 & 0.1 & 0.05 & & 0.05 & 0.1 & 0.05 & & 0.1 & \\
\hline $\mathrm{Cu}$ & $0.057 \pm 0.064$ & $0.021-0.36$ & 0.01 & 1.5 & 1 & & 1 & 1.5 & 1 & & 1 & \\
\hline $\mathrm{Fe}$ & $1.577 \pm 0.997$ & $0.08-4.125$ & 0.3 & 0.3 & 0.5 & & & & 0.5 & 0.5 & 1 & \\
\hline $\mathrm{Cr}$ & $0.047 \pm 0.0519$ & $0.001-0.198$ & 0.01 & & 0.05 & & 0.05 & & 0.05 & & 0.1 & \\
\hline
\end{tabular}

class 1 drinking water without treatment, class 2 bathing, class 3 drinking after treatment, class 4 propagation of wild life, class 5 irrigation and industrial cooling.

${ }^{a}$ Indian Surface water quality criteria for different uses (specified by CPCB, 1979 and the Bureau of Indian Standards, 1982). Available at: https://scclmines.com/env/DOCS/Surface\%20Water\%20Standards.pdf

${ }^{b}$ Environmental Quality Standards for Surface Water. Available at: http://english.mep.gov.cn/SOE/soechina1997/water/standard.htm 
Table 2. Comparison of selected parameters (range or mean) with previous studies from the developing countries.

\begin{tabular}{|c|c|c|c|c|c|c|}
\hline Location & $\mathrm{pH}$ & $\begin{array}{c}\mathrm{DO} \\
(\mathrm{mg} / \mathrm{L})\end{array}$ & $\begin{array}{l}\text { BOD } \\
(\mathrm{mg} / \mathrm{L})\end{array}$ & $\begin{array}{l}\text { COD } \\
(\mathrm{mg} / \mathrm{L})\end{array}$ & $\begin{array}{c}\text { TDS } \\
(\mathrm{mg} / \mathrm{L})\end{array}$ & Reference \\
\hline River Chenab(Pakistan) & $7.02-8.64$ & $7.5-11$ & $1.6-24$ & $4-48$ & $110-550$ & Present study \\
\hline River Chenab(Pakistan) & $8.1-8.3$ & & 28.5 & 99 & & {$[10]$} \\
\hline Indus River (Pakistan) & $7.89-8.96$ & $7.4-12.7$ & & & $200-700$ & [19] \\
\hline Siran River (Pakistan) & $6.7-7.8$ & $4.1-8.5$ & & $8-38$ & $115-214$ & {$[26]$} \\
\hline River Chenab(India) & $7.2-8.5$ & & & & 71.10 & [29] \\
\hline Songhua River (China) & $6.29-8.9$ & & $0.31-67$ & $7.98-197$ & & {$[16]$} \\
\hline Challawa River (Nigeria) & $7.21-10.46$ & $2.67-3.3$ & $10-70$ & $170-570$ & $26-260$ & {$[43]$} \\
\hline Mahanadi River (India) & $7.29-7.39$ & $7.17-7.73$ & $1.36-1.08$ & & $83-111$ & {$[23]$} \\
\hline Gomati River (India) & $6-8.9$ & $0-13.5$ & $0.8-35.8$ & $2.6-76$ & $142-386$ & {$[22]$} \\
\hline Kara Tehran (Iran) & $7.84-8.84$ & $5.6-11.5$ & $0.5-4.4$ & & & {$[24]$} \\
\hline Sabarmati River (India) & $7.03-8.96$ & $0.32-6.27$ & $11.56-133.28$ & $5.14-549.92$ & & {$[27]$} \\
\hline Surma River (Bangladesh) & $5.7-6.9$ & $3.5-7.6$ & $0.6-1.8$ & $0.9-2.6$ & $85-219$ & {$[25]$} \\
\hline Chocancharava River (Argentina) & $8.43-8.07$ & $7.45-9.45$ & & $3.78-4.07$ & 168 & {$[44]$} \\
\hline Shawrawa River (Iraq) & 7.42 & & & & $150-728$ & [45] \\
\hline
\end{tabular}

\section{Statistical Analyses}

Descriptive statistics (mean, standard deviation, range) and multivariate data analysis were performed using Statistica 10.2 software (Stat Soft, Inc., 2010). The cluster analysis (CA), discriminant function analysis (DFA), principal component analysis (PCA) and factor analysis (FA) were performed on the dataset. These techniques would further support elucidating ecological health status through identifying possible sources and water quality parameters responsible for pollution [16]. Hierarchical Agglomerative Cluster Analysis HACA [16] was used for grouping up sites. HACA was applied on the mean concentration data using Ward's method. The squared Euclidean distances were utilized as a tool to measure the similarity between the sampling sites [16]. The variability in water quality data was determined from cluster analysis on spatial basis by the application of linkage distance, stated as Dlink/Dmax $\times 100<20$, which showed the quotient between the linkage distances for a specific case divided by the maximal linkage distance. For standardization of linkage distance the quotient is multiplied by 100 [17].

\section{Results and Discussion}

Descriptive statistics of physiochemical water quality in the Chenab and its comparison with the standards of regional countries, in the absence of any national standards, are summarized in Table 1. During the study period, the water temperature ranged from 9.8 to $23^{\circ} \mathrm{C}$. The mean $\mathrm{pH}$ value was observed to be 7.82 (range: 7.02-8.64), reflecting slight to intermediate alkalinity during both sampling seasons. The $\mathrm{pH}$ values in the present study were found to be comparable or slightly lower than those reported in previous studies from developing countries (Table 2). The DO data from the study period ranged from 7.5 to $11 \mathrm{mg} / \mathrm{L}$, which is acceptable to support aquatic life in the river channel $[5,18]$. The DO levels were found to be comparable to those reported from the Indus River [19]. Total dissolved solids (TDS) ranged from $110 \mathrm{mg} / \mathrm{L}$ to $550 \mathrm{mg} / \mathrm{L}$. The $\mathrm{Cl}, \mathrm{SO}_{4}$ and $\mathrm{Na}$ concentrations have shown significant spatiotemporal variations during the study period, ranging from 10 to $220 \mathrm{mg} / \mathrm{L}$ (mean: $73.31 \mathrm{mg} / \mathrm{L}$ ), 18 to $240 \mathrm{mg} / \mathrm{L}$ (mean: $55.07 \mathrm{mg} / \mathrm{L}$ ) and 2.5 to $145 \mathrm{mg} / \mathrm{L}$ (mean: $25.83 \mathrm{mg} / \mathrm{L}$ ), respectively. The variations in the $\mathrm{Cl}$, $\mathrm{SO}_{4}$ and $\mathrm{Na}$ concentrations were recorded minimum in upper reaches while it increases in downstream sites that might be attributed to wastewater discharges from tannery industrial sector of Sialkot District and the textile industries of Faisalabad District, which uses large amounts of $\mathrm{Cl}, \mathrm{SO}_{4}$ and $\mathrm{Na}$ salts [20]. The biological and chemical oxygen demands have shown considerable spatial, but minimal seasonal (temporal) variations, ranging from $1.6-24$ and $4-48 \mathrm{mg} / \mathrm{l}$, respectively.

The comparison with some previous studies of riverine water quality from Pakistan and some other developing countries (Table 2) revealed that the BOD concentrations in current studies were comparable to those reported in the Pearl River, China [21]; Gomati River, India [22] and the Chenab [10], while higher than those in waters of Mahanadi River, India [23]; Kara Tehran, Iran [24]; and Surma River, Bangladesh [25]. 
The COD levels were comparable or slightly higher than those in the Siran River, Pakistan [26]; Surma River, Bangladesh [25]; and Gomati River, India [22]. However, both the COD and BOD levels in the present study were much lower than those reported in water from the Songhua River, China [16] and the Sabarmati River, India [27].

In order to group up the sites, the water quality results from the Chenab were subjected to hierarchical agglomerative cluster analysis (HACA), which identified three zones. These zones were coded on the basis of relative anthropogenic stress exerted on each zone as: i) least-stressed zone (LSZ), encompassing five upstream sampling sites, i.e. Sites 1 to 5 ; ii) moderately stressed zone (MSZ), including Sites 6 and 7; and iii) highly stressed zone (HSZ) covering the downstream Sites 8 and 9 (Fig. 2). At the LSZ, the minimum stress was attributed to greater volume of water available, diluting the pollutants. In contrast, the MSZ receives polluted water of Faisalabad (a highly industrialized city), and the HSZ receives wastewater from Multan District along with flow from River Ravi carrying the wastewater of Lahore city and surroundings industrial areas that worsens the pollution manifold.

\section{Variation in Surface Water Quality on Spatial Basis}

Discriminant function analysis (DFA) of the results highlighted the spatial variations across most significant variables. Water quality data was plotted as independent variables and DFA was applied in three modes, i.e. standard, forward and backward stepwise modes. Classification matrices of the DFA have shown spatial classification accuracies of standard, forward and backward stepwise modes as 97.61\%, 92.85\% and $86.2 \%$, respectively (Table 3 ). The results of the DFA revealed that all the parameters were found with significant variation in standard stepwise mode. The DFA discriminated most significant variables, i.e.

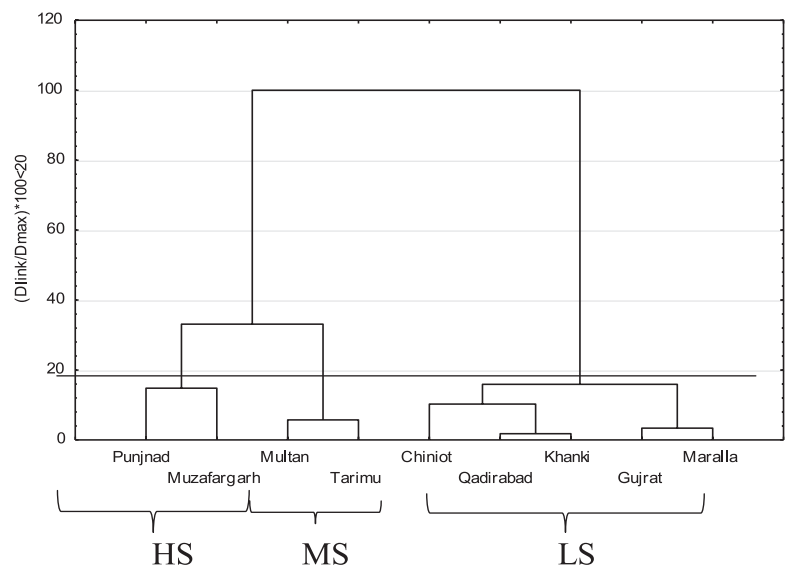

Fig. 2. Dendrogram of different clusters of sampling sites located along the Chenab River.
$\mathrm{COD}, \mathrm{Cl}, \mathrm{SO}_{4}, \mathrm{~K}, \mathrm{Cu}, \mathrm{Cd}$ and $\mathrm{Pb}$ on spatial basis. The variables selected by DFA through backward stepwise mode were given in Fig. 3 in the form of box-whisker plots.

The LSZ has a low COD level (mean $4.0 \mathrm{mg} / \mathrm{L}$ ) that was observed to be increased significantly downstream in the HSZ, i.e., $48 \mathrm{mg} / \mathrm{L}$. The municipal and industrial wastewater discharges contribute to organic pollution, which increase the COD level. The DO content in water decreases as a result of aerobic decomposition of organic pollutants by microorganisms [28].

The decrease in DO level at HSZ (up to $7.5 \mathrm{mg} / \mathrm{L}$ ) indicates uncontrolled disposal of effluents from industrial and domestic sources. Increased concentration of heavy metals and high TDS levels also validate the untreated wastewater disposal to the river. Another contributing factor is the diversion of Chenab's water via link and irrigation canals that substantially reduce dilution.

Copper $(\mathrm{Cu})$ concentration was found to be in the range of 0.02 to $0.362 \mathrm{mg} / \mathrm{L}$. Previously, $\mathrm{Cu}$ in the upper reaches of the Chenab ranged from 0.01 to $0.11 \mathrm{mg} / \mathrm{L}$ [29]. Yet the determined levels of $\mathrm{Cu}$ were within limits as compared to the NEQS $(1 \mathrm{mg} / \mathrm{L})$ and WHO drinking water $(2 \mathrm{mg} / \mathrm{L})$ limits. High lead values (mean $0.08 \mathrm{mg} / \mathrm{L}$ ) greater than the permissible limit $(0.01 \mathrm{mg} / \mathrm{L})$ have been reported in the upper reaches of the Chenab - linked with bad sanitation on both the banks of the river [29]. Whereas Gupta et al. [30] has connected higher $\mathrm{Pb}$ contents in various aquatic systems of Jammu and Kashmir State associated with vehicular emissions. $\mathrm{Pb}$ was reported from $\mathrm{BDL}$ (below detection limit) to $0.38 \mathrm{mg} / \mathrm{L}$ in surface water in different areas of the state. The lead level in surface water has been exceeding as compared to ground water samples in major cities of Pakistan, where almost $15 \%$ of surface water and $1 \%$ of groundwater specimens had lead contamination above the permissible limits [31]. A major source of lead is the use of leaded gasoline as discussed [30]. Other sources include lead-based batteries, and when these batteries are burnt to recover lead it is added to air, which ultimately comes to ground with rainwater [32]. Chloride $\left(\mathrm{Cl}^{-}\right)$contamination is an indication of the addition of sewage discharge [33], tanneries $[34,35]$ and textile industrial sector wastewater [19] into riverine water. Sources of cadmium (Cd) and sulphate $\left(\mathrm{SO}_{4}\right)$ are discussed in source identification para.

\section{Variation in Surface Water Quality on Temporal Basis}

The seasonal variations were evaluated through the application of DFA on available data after its segregation into two seasonal groups, i.e., dry and wet seasons. Similarly, the classification functions and matrix were acquired from standard, forward and backward stepwise modes (Table 4). 
a)

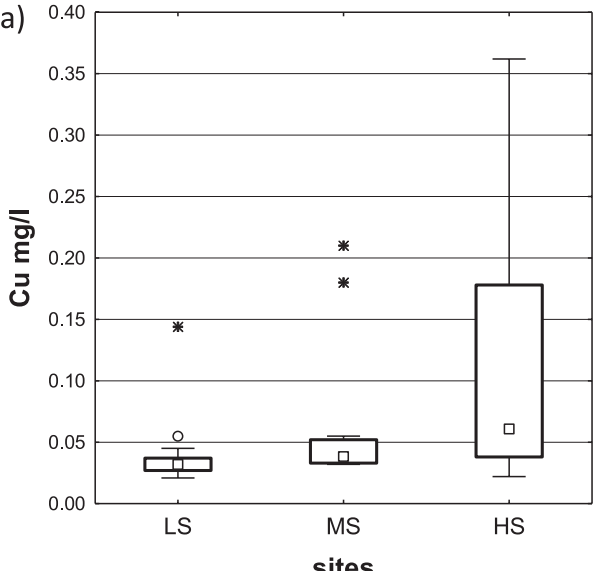

c)

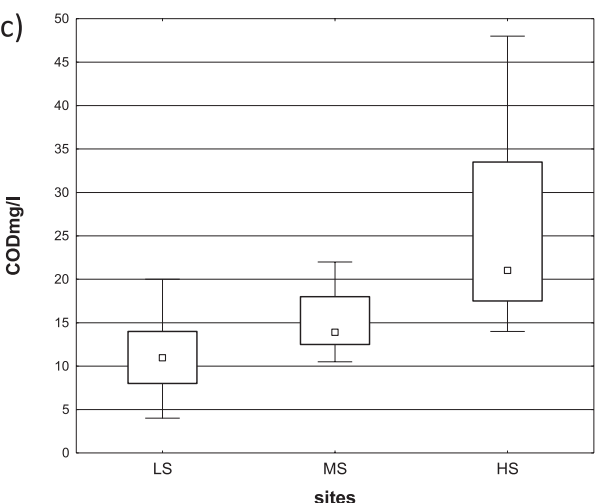

e)

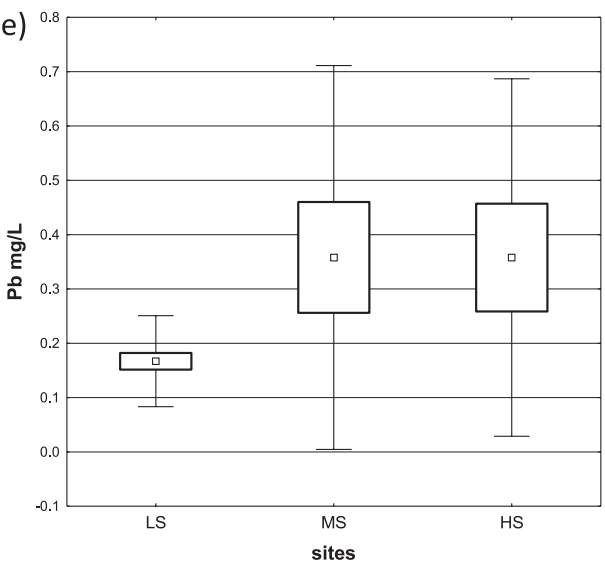

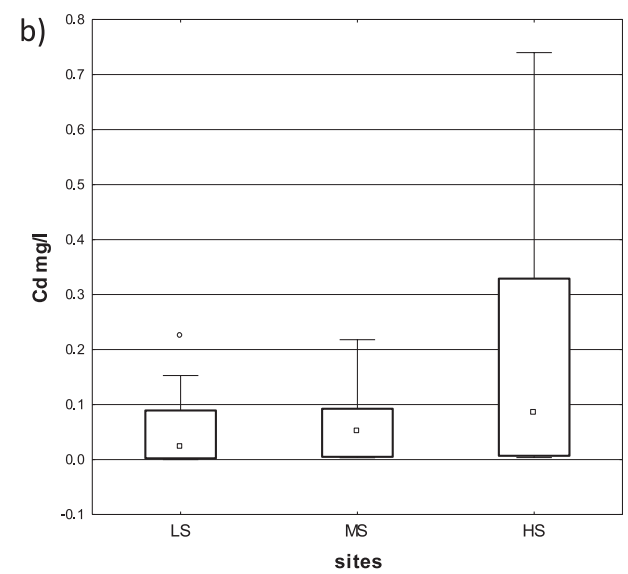
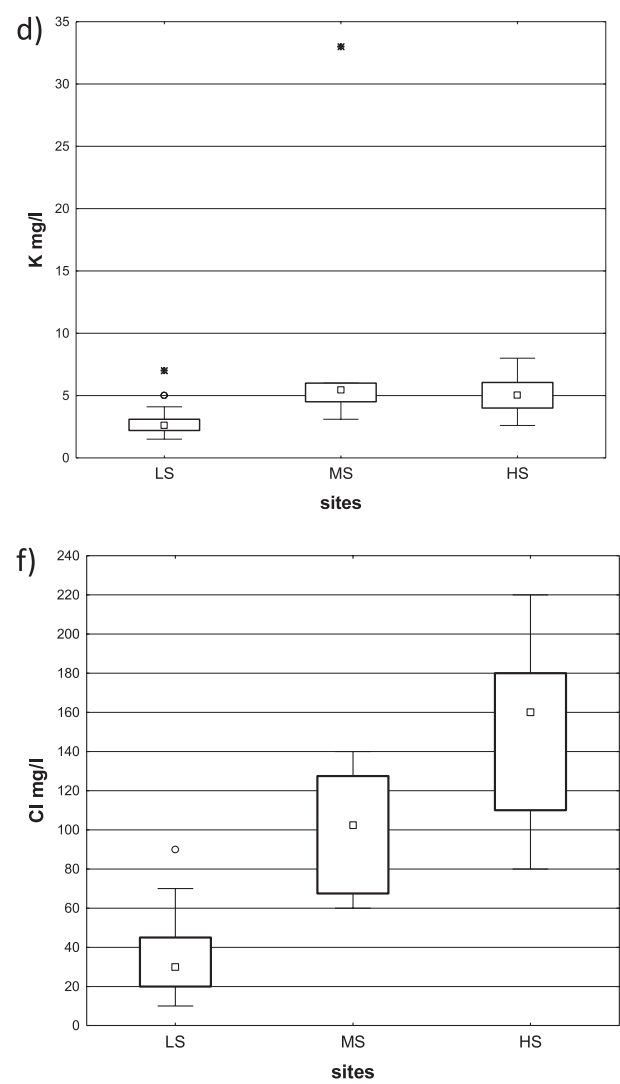

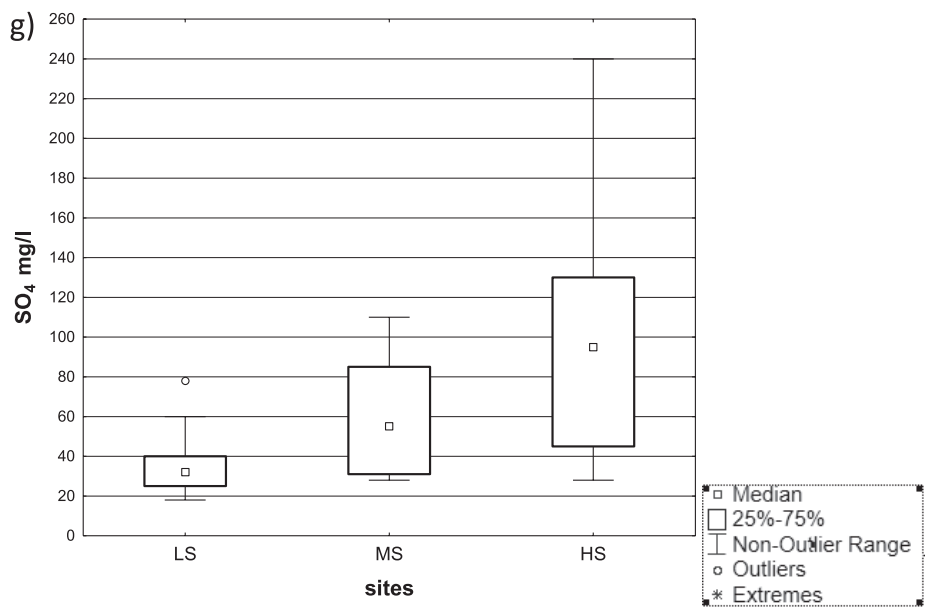

Fig. 3. Box and whisker plots of parameters selected in backward mode: a) $\mathrm{Cu}$, b) $\mathrm{Cd}$, c) $\mathrm{COD}$, d) $\mathrm{K}$, e) $\mathrm{Pb}$, f) $\mathrm{Cl}$ and g) $\mathrm{SO}_{4}$, separated by spatial discriminant analysis applied on water quality data of the Chenab River. 
Table 3. Discriminant function analysis for water quality parameters with respect to zones of River Chenab, Punjab.

\begin{tabular}{|c|c|c|c|c|c|c|c|c|c|}
\hline \multirow{2}{*}{ Parameter } & \multicolumn{3}{|c|}{ Standard } & \multicolumn{3}{|c|}{ Forward } & \multicolumn{3}{|c|}{ Backward } \\
\hline & LSZ & MSZ & HSZ & LSZ & MSZ & HSZ & LSZ & MSZ & HSZ \\
\hline Temp & 9.96 & 10.95 & 10.39 & & & & & & \\
\hline $\mathrm{pH}$ & 74.34 & 69.905 & 72.50 & 28.55 & 26.38 & 27.79 & & & \\
\hline DO & 65.71 & 64.919 & 67.10 & & & & & & \\
\hline TDS & 0.46 & 0.471 & 0.58 & 0.06 & 0.07 & 0.17 & & & \\
\hline TSS & 0.59 & 0.608 & 0.58 & & & & & & \\
\hline BOD & -19.2 & -22.33 & -23.8 & & & & & & \\
\hline COD & 4.64 & 5.292 & 6.07 & 1.44 & 0.85 & 5.04 & 0.57 & 0.89 & 1.54 \\
\hline $\mathrm{Cl}$ & -0.42 & -0.219 & -0.13 & -0.59 & -0.37 & -0.31 & -0.02 & 0.15 & 0.18 \\
\hline $\mathrm{SO}_{4}$ & 0.93 & 0.860 & 1.20 & 0.64 & 0.52 & 0.78 & 0.081 & 0.01 & 0.21 \\
\hline S & 7.73 & 6.742 & 11.46 & & & & & & \\
\hline $\mathrm{F}$ & -259. & -252.0 & -289 & 6.06 & 10.34 & -16.70 & & & \\
\hline $\mathrm{Na}$ & -0.53 & -0.543 & -0.66 & 0.00 & -0.002 & -0.11 & & & \\
\hline $\mathrm{Ca}$ & -2.63 & -2.283 & -2.46 & & & & & & \\
\hline K & 11.80 & 11.699 & 5.54 & 3.10 & 3.58 & -2.39 & 1.77 & 1.87 & -2.75 \\
\hline $\mathrm{Cu}$ & 209.63 & 218.635 & 339.25 & 67.60 & 66.92 & 179.78 & 49.581 & 61.12 & 191.23 \\
\hline $\mathrm{Cr}$ & -49.27 & -17.034 & 19.12 & -8.56 & 18.43 & 48.66 & & & \\
\hline $\mathrm{Cd}$ & 104.24 & 96.589 & 51.12 & -21.26 & -30.14 & -70.63 & -7.69 & -21.41 & -58.69 \\
\hline $\mathrm{Fe}$ & 30.91 & 32.285 & 35.70 & & & & & & \\
\hline $\mathrm{Pb}$ & 36.90 & 35.787 & 79.90 & 29.05 & 31.048 & 70.8 & 10.35 & 16.17 & 40.80 \\
\hline Constant & -695.8 & -691.447 & -770.9 & -129.6 & -129.6 & -180.7 & -8.55 & -24.76 & -52.83 \\
\hline Classification Matrices & $100 \%$ & $88.889 \%$ & $100 \%$ & $96.29 \%$ & $77.77 \%$ & $100 \%$ & $96.55 \%$ & $75.00 \%$ & $70.00 \%$ \\
\hline
\end{tabular}

The temporal variation classification function accuracies were calculated to be $75 \%, 86 \%$ and $95 \%$ for backward, forward and standard stepwise modes, respectively. In forward stepwise DFA, nine variables, including $\mathrm{pH}, \mathrm{DO}, \mathrm{TDS}, \mathrm{S}, \mathrm{Cl}, \mathrm{F}, \mathrm{Ca}, \mathrm{Cr}$ and $\mathrm{Fe}$, were found to be considerable. Whereas in backward stepwise DFA, the TDS, Cl, F, S and $\mathrm{Ca}$ were discriminated as significant (Fig. 4). All the studied parameters reflected a relative decrease in concentrations during wet season as compared to dry season, except for $\mathrm{Pb}$ levels. During the high flow season (i.e. wet season), the concentration of pollutants decreased due to an increase in dilution factor [5]. These results demonstrated a minimal effect of nonpoint pollution sources as though surface runoff increases during wet season, yet the pollutant concentration does not rise; however the pollutant discharge from point sources remains constant during both seasons [36].

\section{Source Identification}

Principal component analysis (PCA) based on factor analysis was applied separately on three previously recognized groups, LSZ, MSZ and HSZ, to assess the possible sources of pollution and to recognize considerable factors accounting for variation in water quality (Table 5). For each zone, varimax raw rotation was utilized on PCA with eigenvalue greater than 1 in order to generate the varimax factors (VF). The varimax factors coefficients with correlation values more than 0.70 were merely considered. Sources were recognized on the basis of information available and collected during field sampling about the different activities carried out in the region. For LSZ, out of three varimax factors, VF1 has shown $25.75 \%$ of the total variance and had a strong positive correlation with $\mathrm{Cl}(\mathrm{r}=0.72), \mathrm{SO}_{4}(\mathrm{r}=0.76), \mathrm{S}(\mathrm{r}=0.72), \mathrm{F}(\mathrm{r}=0.73)$, $\mathrm{Na}(\mathrm{r}=0.79)$ and $\mathrm{K}(\mathrm{r}=0.74)$. The possible sources of these pollutants are industrial activities in the area. The upstream study area comprised of tannery, rubber and surgical instruments, chemical and electroplating industries [37]. Sodium, chloride and sulphide were added from tannery wastewater [35], where sulphides are converted to $\mathrm{SO}_{4}$ by the bacterial activities. $\mathrm{SO}_{4}$ is also being added by the textile industrial sector as well as municipal sewage, whereas the extensive agriculture activities in the adjacent area are a possible source of 
$\mathrm{K}^{+}$being added to the Chenab as it is a key component of potash fertilizer [38, 39], and whereas the VF2 and VF3 described 19.5 and $14.4 \%$ of total variance. The VF2 had positive correlation with BOD $(r=0.70)$, which might be associated with the discharge of domestic sewage from the densely populated upstream cities, i.e. Sialkot, Mandi Bahauddin, Gujrat, Gujranwala, Hafizabad and Sargodha, contributing high organic load through municipal sewage as well as industrial wastewater. Whereas VF3 has shown strong positive correlation with $\mathrm{pH}(\mathrm{r}=0.76), \mathrm{Cd}(\mathrm{r}=0.82)$ and strong negative correlation with DO $(r=-0.80)$. Discharge of municipal and industrial wastewater adds heavy metals in the riverine water that also results in $\mathrm{pH}$ fluctuation. Whereas cadmium is released in environment from surgical instruments manufacturing units, chemical and electroplating industries [37], agricultural activities [40] and vehicular emissions [41]. The negative loading of
DO is due to high organic matter present in the water that is being decomposed aerobically by microbes, consuming the DO in water $[28,36]$.

In the case of group 2 (MSZ), VF1 has shown $34.18 \%$ of the total variance and strong positive correlation with $\mathrm{pH}(\mathrm{r}=0.84), \mathrm{Cd}(\mathrm{r}=0.93)$, $\mathrm{Fe}(\mathrm{r}=0.76)$ and $\mathrm{Cu}(\mathrm{r}=0.73)$; and a negative correlation with $\mathrm{SO}_{4}(\mathrm{r}=-0.86)$ and $\mathrm{Na}(\mathrm{r}=-0.71)$. This zone is highly polluted as a vastly industrialized city (Faisalabad) is located in this region, and includes the largest textile sector of Pakistan.

Textile wastewater consists of dyeing and finishing salts (such as sodium sulphate and sodium chloride) [42]. Dyeing in the textile industry is a significant source of heavy metal, which is also intimated with high levels of cadmium, copper and iron in this zone. However, the Jhelum River confluence with the Chenab, upstream to Trimmu headwork, causes a decrease in pollutant
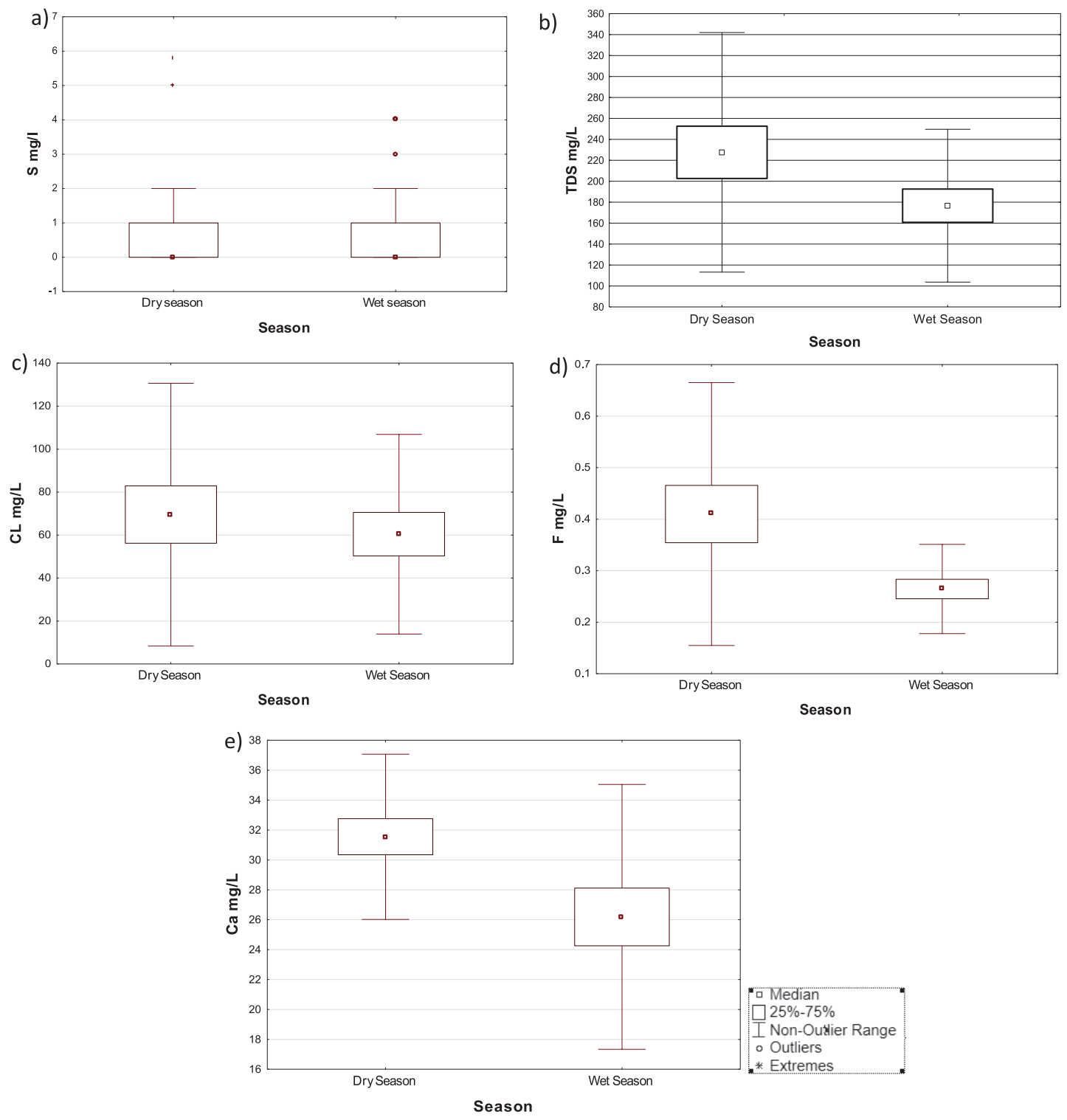

Fig. 4. Box and whisker plots of parameters selected in backward mode: a) S, b) TDS, c) Cl, d) F and e) Ca, separated by temporal discriminant analysis applied on water quality data of the Chenab River. 
Table 4. Classification functions for discriminant function analysis of Chenab River water quality variation on a temporal basis (i.e., wet and dry seasons)

\begin{tabular}{|c|c|c|c|c|c|c|}
\hline \multirow{2}{*}{ Parameter } & \multicolumn{2}{|c|}{ Standard } & \multicolumn{2}{|c|}{ Forward } & \multicolumn{2}{|c|}{ Backward } \\
\hline & Dry season & Wet & Dry season & Wet & Dry & Wet \\
\hline Temp & 5.354 & 6.051 & & & & \\
\hline $\mathrm{pH}$ & 128.918 & 122.915 & 116.963 & 113.077 & & \\
\hline DO & 49.829 & 50.254 & 27.839 & 26.778 & & \\
\hline TDS & 0.603 & 0.543 & 0.581 & 0.520 & 0.110 & 0.077 \\
\hline TSS & 0.495 & 0.518 & & & & \\
\hline BOD & -5.370 & -7.035 & & & & \\
\hline $\mathrm{COD}$ & 1.185 & 1.421 & & & & \\
\hline CL & -0.900 & -0.778 & -0.753 & -0.606 & -0.338 & -0.229 \\
\hline $\mathrm{SO}_{4}$ & 0.181 & 0.250 & & & & \\
\hline $\mathrm{S}$ & -4.259 & -2.527 & -2.710 & -1.380 & -3.637 & -2.363 \\
\hline $\mathrm{F}$ & -84.346 & -108.989 & 87.348 & 69.879 & 45.066 & 28.412 \\
\hline $\mathrm{Na}$ & -0.315 & -0.342 & & & & \\
\hline $\mathrm{Ca}$ & -1.433 & -1.736 & -0.502 & -0.818 & 1.263 & 0.936 \\
\hline $\mathrm{K}$ & 19.032 & 19.022 & & & & \\
\hline $\mathrm{Cu}$ & 29.631 & 47.812 & & & & \\
\hline $\mathrm{Cr}$ & -313.810 & -278.646 & -248.722 & -222.113 & & \\
\hline $\mathrm{Cd}$ & 160.658 & 157.469 & & & & \\
\hline $\mathrm{Fe}$ & 19.939 & 20.127 & 10.048 & 8.961 & & \\
\hline $\mathrm{Pb}$ & -4.951 & -2.660 & & & & \\
\hline Constant & -840.471 & -790.564 & -641.303 & -584.148 & -29.787 & -15.793 \\
\hline Classification Matrices & $95.23 \%$ & $95.23 \%$ & $80.95 \%$ & $86.36 \%$ & $70.37 \%$ & $81.48 \%$ \\
\hline
\end{tabular}

concentrations due to dilution. Whereas VF2 have shown strong positive correlation with BOD $(\mathrm{r}=0.91)$, $\mathrm{COD}(\mathrm{r}=0.86)$ and $\mathrm{Ca}(\mathrm{r}=0.89)$. The possible sources of these pollutants are domestic sewage and industrial wastewater from Chinniot, Hafizabad, Pindi Bhatian and Faisalabad in this region. The strong positive loading of the COD and BOD observed was consistent with the fact that heavily populated and industrialized areas are responsible for strong positive loading of organic load [20]. The VF3 (17.8\% of total variance) has shown positive loading on TDS $(\mathrm{r}=0.83), \mathrm{Cl}(\mathrm{r}=0.79)$, $\mathrm{F}(\mathrm{r}=0.73)$ and $\mathrm{K}(\mathrm{r}=0.77)$, and a negative correlation with $\mathrm{Pb}(\mathrm{r}=-0.80)$.

In the case of group 3 (HSZ), encompassing sites Muzaffargarh and Punjnad, VF1 has shown $51.82 \%$ of the total variance and it showed a positive correlation with TDS $(\mathrm{r}=0.71), \mathrm{Cl}(\mathrm{r}=0.89)$ and $\mathrm{SO}_{4}(\mathrm{r}=0.86)$, and a negative loading with $\mathrm{pH}(\mathrm{r}=-0.76), \mathrm{Fe}(\mathrm{r}=-0.90)$, $\mathrm{Cu}(\mathrm{r}=-0.98), \mathrm{Cr}(\mathrm{r}=-0.96)$ and $\mathrm{Pb}(\mathrm{r}=-0.95)$. The trend is representing reduction in metal pollution associated with industrial discharge, while the agriculture and domestic sewage pollution is possibly increasing at this zone. Reduction in heavy metal pollution may also be attributed to dilution factor enhancement due to the addition of water from the Indus River through Taunsa-Punjnad Link Canal. VF2 (with $26.8 \%$ of total variance) shows strong positive correlation with BOD $(\mathrm{r}=0.98), \mathrm{COD}(\mathrm{r}=0.99), \mathrm{F}(\mathrm{r}=0.72)$ and $\mathrm{Cd}(\mathrm{r}=0.83)$, and negative correlation with DO $(\mathrm{r}=-0.76)$, possibly due to DO depletion because of domestic sewage and agricultural runoff, containing high BOD and COD contents, whereas VF3 shows a total variance of $13 \%$ with a strong positive correlation on temperature $(\mathrm{r}=0.88), \mathrm{S}(\mathrm{r}=0.71)$ and $\mathrm{K}(\mathrm{r}=0.85)$. The positive correlation is possibly due to a relative increase in ambient temperature as compared to upstream sites and intensive agricultural activities in the area.

At the same time, PCA was performed on data from wet and dry seasons to evaluate the temporal variations. The produced VFs were plotted in the form of biplots as shown in Fig. 5, providing valuable information about the seasonality of pollutants. The parameters with stronger correlation were marked. During the dry season, the variables with strong positive loading at 
Table 5. Loadings of environmental variables on the first three Varimax normalized rotated principle components for water quality data collected from the LSZ, MSZ and HSZ of the Chenab River.

\begin{tabular}{|c|c|c|c|c|c|c|c|c|c|}
\hline \multirow{2}{*}{ Parameter } & \multicolumn{3}{|c|}{ LSZ } & \multicolumn{3}{|c|}{ MSZ } & \multicolumn{3}{|c|}{ HSZ } \\
\hline & VF1 & VF2 & VF3 & VF1 & VF2 & VF3 & VF1 & VF2 & VF3 \\
\hline Temp & & & & & & & & & 0.887 \\
\hline $\mathrm{pH}$ & & & 0.763 & 0.841 & & & -0.760 & & \\
\hline DO & & & -0.802 & & & & & -0.765 & \\
\hline TDS & & & & & & 0.831 & 0.716 & & \\
\hline TSS & & & & & & & & & \\
\hline BOD & & 0.708 & & & 0.912 & & & 0.985 & \\
\hline $\mathrm{COD}$ & & & & & 0.867 & & & 0.992 & \\
\hline $\mathrm{CL}$ & 0.723 & & & & & 0.791 & 0.901 & & \\
\hline $\mathrm{SO}_{4}$ & 0.767 & & & -0.86 & & & 0.864 & & \\
\hline $\mathrm{S}$ & 0.721 & & & & & & & & 0.715 \\
\hline $\mathrm{F}$ & 0.736 & & & & & 0.739 & & 0.721 & \\
\hline $\mathrm{Na}$ & 0.799 & & & -0.712 & & & 0.8425 & & \\
\hline $\mathrm{Ca}$ & & & & & 0.897 & & & & \\
\hline $\mathrm{K}$ & 0.742 & & & & & 0.772 & & & 0.859 \\
\hline $\mathrm{Cu}$ & & & & 0.739 & & & -0.986 & & \\
\hline $\mathrm{Cr}$ & & & & & & & -0.961 & & \\
\hline $\mathrm{Cd}$ & & & 0.822 & 0.937 & & & & 0.840 & \\
\hline $\mathrm{Fe}$ & & & & 0.769 & & & -0.907 & & \\
\hline $\mathrm{Pb}$ & & & & & & -0.804 & -0.953 & & \\
\hline Expl. Var & 4.687 & 3.579 & 3.076 & 5.221 & 3.937 & 4.755 & 8.623 & 5.816 & 2.994 \\
\hline Prp. Totl & 0.246 & 0.188 & 0.162 & 0.275 & 0.207 & 0.250 & 0.454 & 0.306 & 0.158 \\
\hline *Source & IND, GR, NA & MUN & MUN, IND & IND & MUN, IND & IND, AGR & MIS & MUN, AGR & AGR \\
\hline Eigenvalue & 4.893 & 3.714 & 2.736 & 6.495 & 4.020 & 3.399 & 9.846 & 5.108 & 2.479 \\
\hline
\end{tabular}

*IND - industry, AGR - agriculture, NA - natural, MUN - municipal, MIS - miscellaneous

VF1 were found to be TDS, TSS, BOD, $\mathrm{COD}, \mathrm{Cl}, \mathrm{SO}_{4}$, $\mathrm{F}$ and $\mathrm{Na}$; attributing to low influx of river water and lower dilution of effluent discharged. While VF2 depicts positive loading on $\mathrm{K}, \mathrm{Fe}, \mathrm{Pb}$ and $\mathrm{Ca}$. The overall picture of seasonal variation has portrayed that during dry season, the metals content along with organic load raises that also possibly related to increased solids load (both dissolved and suspended fractions), whereas during wet season strong positive loading has been depicted by VF1 on TDS, $\mathrm{Cl}, \mathrm{SO}_{4}, \mathrm{~F}, \mathrm{Na}$ and $\mathrm{K}$, and $\mathrm{VF} 2$ on $\mathrm{pH}, \mathrm{BOD}$, $\mathrm{COD}, \mathrm{Cu}, \mathrm{Cr}$, Fe and $\mathrm{Pb}$ (Fig. 5).

Generally, it is evident from the analysis that the heavy metal pollution was greater in the wet season. The possible source of heavy metal contamination is agricultural activities and industrial discharge along with air emissions that might be added related to surface water due to enhanced atmospheric deposition in wet season. So, the dire need of the time to control air pollution along with industrial effluent and put some limits on the use of heavy metal-based dyes and pesticides. This highlights the fact that the deterioration of Chenab water quality is evident due to wastewater discharges, atmospheric deposition and agricultural runoff that is further intensified due to flow modification through link canals, possessing a serious threat to aquatic ecosystems. Therefore, regular monitoring and management is warranted to protect the ecological integrity.

\section{Conclusion}

The present study presented the water quality status of the Chenab River due to anthropogenic stress. The variations in the concentrations on contaminants in the river stretch were recorded as minimum in upper 


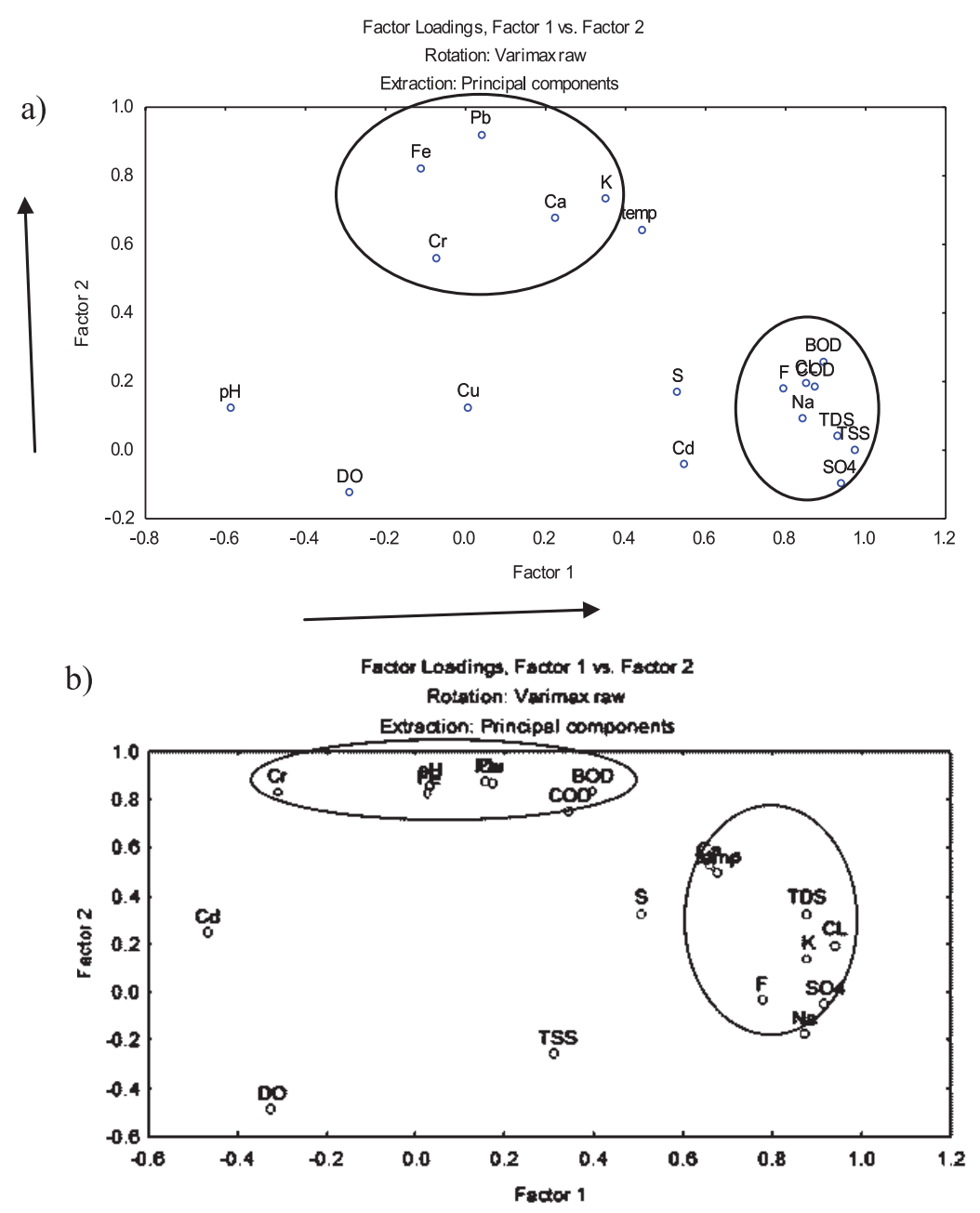

Fig. 5. Scatter plot of loading of: a) VF1 (44.8\%) and VF2 (17.34\%) for dry season, b) VF1(44\%) and VF2(22.49\%) for wet season.

reaches that increases in downstream sites, and the increase might be significantly attributed to wastewater discharges, and water diversions through link canals. The DFA identified $\mathrm{COD}, \mathrm{Cl}, \mathrm{SO}_{4}, \mathrm{~K}, \mathrm{Cu}, \mathrm{Cd}$ and $\mathrm{Pb}$ as the most significant variables on a spatial basis, while on a temporal basis all study parameters reflected a relative decrease in concentrations during the wet season as compared to dry season, except for Pb levels. Most lead is added from across the border as a transboundary pollutant. Therefore, regular monitoring, wastewater and runoff management is warranted to protect the ecological integrity. This study is a pioneer in the field of anthropogenic stress from Pakistan and will provide a database for further work and will assist managers for setting sampling strategy, i.e., selecting the number and times of sampling.

\section{Acknowledgments}

The authors would like to thank officers of the Punjab Environment Protection Department, especially Director General Maqsood Ahmed Lak for allowing analysis of samples in the EPD Laboratory, and Tariq
Javed, research assistant of the laboratory, for his help in the sampling program. We extend our gratitude to the Punjab Irrigation Department, particularly Fozia Sardar for helping in analysis of samples and data, and Mohammad Rafique, chief engineer of the Faisalabad Zone, for providing information regarding discharge.

\section{Conflict of Interest}

The authors declare no conflict of interest.

\section{References}

1. AnHWAngEB A., AGBAJIE B., GIMBAE C. Impact assessment of human activities and seasonal variation on River Benue, within Makurdi Metropolis. Int. J. Sci. Tech., 2 (5), 248, 2012.

2. JAMIL N., BAQAR M., SHAIKH I.A. Assessment of contamination in water and soil surrounding a chlor-alkali plant: a case study. J. Chem. Soc. Pakistan., 37 (1), 173, 2015.

3. ARCHER D.R., FORSYTHE N., FOWLER H.J., SHAH S.M. Sustainability of water resources management in the 
Indus Basin under changing climatic and socioeconomic conditions. Hydrol. Earth Sys. Sc., 14 (8), 1669, 2010.

4. KAMAL P., HEMANGI D., HITESHD. Impact of industrialization and urbanization on water quality of river Tapi Surat, Gujarat, India. J. Environ. Res. Dev., 9 (2), 306, 2014.

5. QADIR A., MALIK R. N., HUSAIN S. Z. Spatio-temporal variations in water quality of Nullah Aik-tributary of the river Chenab, Pakistan. Environ. Monit. Assess., 140 (1), 43, 2008.

6. MALIK R.N., MOECKEL C., JONES K.C., HUGHES D. Polybrominated diphenyl ethers (PBDEs) in feathers of colonial water-bird species from Pakistan. Environ. Pollut., 159 (10), 3044, 2011.

7. SYED J.H., MALIK R.N., LI J., CHAEMFA C., ZHANG G., JONES K.C. Status, distribution and ecological risk of organochlorines (OCs) in the surface sediments from the Ravi River, Pakistan. Sci. Total Environ. 472, 204, 2014.

8. MISHRA A. Assessment of water quality using principal component analysis: a case study of the river Ganges. J. Water Chem. Technol., 32 (4), 227, 2010.

9. SUN R., LUO X., TANG B., LI Z., WANG T., TAO L., MAI B. Persistent halogenated compounds in fish from rivers in the Pearl River Delta, South China: Geographical pattern and implications for anthropogenic effects on the environment. Environ. Res., 146, 371, 2016.

10. BHATTI M.T., LATIF M. Assessment of water quality of a river using an indexing approach during the low-flow season. Irrig. Drain., 60 (1), 103, 2011.

11. EQANI S., MALIKR. N., MOHAMMAD, A. The level and distribution of selected organochlorine pesticides in sediments from River Chenab, Pakistan. Environ. Geochem. Hlth., 33 (1), 33, 2011.

12. EQANI S., MALIK R.N., KATSOYIANNIS A., ZHANG G., CHAKRABORTY P., MOHAMMAD A., JONES K.C. Distribution and risk assessment of organochlorine contaminants in surface water from River Chenab, Pakistan. J. Environ. Monit., 14 (6), 1645, 2012.

13. AZIZULLAH A., KHATTAK M.N.K., RICHTER P., HÄDER D.P. Water pollution in Pakistan and its impact on public health - a review. Environ. Int., 37 (2), 479, 2011.

14. KOKLU R., SENGORUR B., TOPAL B. Water quality assessment using multivariate statistical methods - a case study: Melen River System (Turkey). Water Resour. Manag., 24 (5), 959, 2010.

15. American Public Health Association (APHA). Standard Methods for the Examination of Water and Wastewater. ( $21^{\text {st }}$ ed.). American Public Health Association, New York, 2005.

16. WANG Y., WANG P., BAI Y., TIAN Z., LI J., SHAO X., MUSTAVICH L. F., LI B. L. Assessment of surface water quality via multivariate statistical techniques: a case study of the Songhua River Harbin region, China. J. HydroEnviron. Res., 7 (1), 30, 2013.

17. JUAHIR H., ZAIN S.M., YUSOFF M.K., HANIDZA T.T., ARMI A.M., TORIMAN M.E., MOKHTAR M. Spatial water quality assessment of Langat River Basin (Malaysia) using environmetric techniques. Environ. Monit. Assess., 173, 625, 2011.

18. KUMAR M., PURI A. A review of permissible limits of drinking water. Indian J. Occup. Environ. Med., 16 (1), 40, 2012.

19. ALI M., SALAM A., AHMED N., KHAN A., KHOKHAR M.Y. Monthly variation in physico-chemical characteristics and metal contents of Indus River at Ghazi
Ghat, Muzaffargarh, Pakistan. Pak. J. Zool., 36 (4), 295, 2004.

20. MASOOD F., MALIK A. Environmental Concerns of the Tanning Industry. Environmental Deterioration and Human Health, Springer Netherlands, 2014.

21. ZHANG Y., GUO F., MENG W., WANG X. Q. Water quality assessment and source identification of Daliao river basin using multivariate statistical methods. Environ. Monit. Assess., 152 (1-4), 105, 2009.

22. SINGH K.P., MALIK A., SINHA S. Water quality assessment and apportionment of pollution sources of Gomti river (India) using multivariate statistical techniques - a case study. Anal. Chim. Acta., 538, 355, 2005.

23. SUNDARAY S.K., PANDA U.C., NAYAK B.B., BHATTA D. Multivariate statistical techniques for the evaluation of spatial and temporal variations in water quality of the Mahanadi river - estuarine system (India) - a case study. Environ. Geochem. Health., 28 (4), 317, 2006.

24. GHOLIKANDI G.B., HADDADI S., DEHGHANIFARD E., TASHAYOUIE H.R. Assessment of surface water resources quality in Tehran province, Iran. Desalin. Water Treat., 37, 8, 2012.

25. ALAM M.J., ISLAM M.R., MUYEN Z., MAMUN M., ISLAM S. Water quality parameters along rivers. Int. J. Environ. Sci. Tech., 4 (1), 159, 2007.

26. ZEB B.S., MALIK A.H., WASEEM A., MAHMOOD Q. Water quality assessment of Siran river, Pakistan. Int. J. Phy. Sci., 6 (34), 7789, 2011.

27. KUMAR R.N., SOLANKI R., KUMAR N. An assessment of seasonal variation and water quality index of Sabarmati River and Kharicut canal at Ahmedabad, Gujarat. Electron. J. Environ. Agric. Food Chem., 5, 2248, 2011.

28. BIERMAN P., LEWIS M., OSTENDORF B., TANNER J. A review of methods for analysing spatial and temporal patterns in coastal water quality. Ecol. Ind., 11 (1), 103, 2011.

29. FOTEDAR A., LOAN B.A., FOTEDAR B.K. Water Quality Assessment of the River Chenab, Flowing from Pul Doda to Baggar (J \& K State), for Domestic Use. Nature Environ. Pollut. Tech., 9 (4), 719, 2010.

30. GUPTA R.D. Environmental degradation of Jammu \& Kashmir Himalayas and their control. Associated Publishing Company, India, 2005.

31. Pakistan Council for Research in Water Resources (PCRWR). National Water Quality Monitoring Programme. Water Quality Report 2003-2004. Islamabad: Pakistan Council for Research in Water Resources, 2005. Available http://www.pcrwr.gov.pk/wq_phase3_report/ TOC.htm.

32. VIJAYAKUMAR S., SASIKALA M., RAMESH R. Lead poisoning - an overveiw. Int. J. Pharmacol. Toxicol., 2, 70, 2012.

33. UMAVATHI S., LOGANKUMAR K., SUBHASHINI S., LOGASWAMY S. Studies on the nutrient content of sulur pond Coimbatore. Ecol. Environ. Conserv., 13, 501, 2007.

34. SANCHEZ-TRIANA E., ORTOLANO L., AFZAL J. Green Industrial Growth: Mainstreaming Environmental Sustainability in Pakistan's Industrial Sector. Washington DC: World Bank, 2012.

35. DETTMER A., CAVALLI É., AYUB M.A., GUTTERRES M. Environmentally friendly hide unhairing: enzymatic hide processing for the replacement of sodium sulfide and delimig. J. Clean. Prod., 47, 11, 2013.

36. FÖRSTNER U., WITTMANN G.T. Metal pollution in the aquatic environment. Springer-Verlag, Berlin, 2012. 
37. ALI Z., MALIK R.N., QADIR A. Heavy metals distribution and risk assessment in soils affected by tannery effluents. Chem. Ecol. 29 (8), 676, 2013.

38. VALENTE M.L., CRUZ J.C., BAGGIOTTO C., CONSENSA C.B. Influential Factors in Surface Water Quality in catchments within the Pampa Biome with different Land Usel Revista Árvore, 39 (6), 1135, 2015

39. MOHAMMED S.M.O., BRANDT K., GRAY N.D., WHITE M.L., MANNING D.A.C. Comparison of silicate minerals as sources of potassium for plant nutrition in sandy soil. Eur. J. Soil Sci., 65 (5), 653, 2014.

40. MUTIA T.M., VIRANI M.Z., MOTURI W.N., MUYELA B., MAVURA W.J., LALAH J.O. Copper, lead and cadmium concentrations in surface water, sediment and fish, C. Carpio, samples from Lake Naivasha: effect of recent anthropogenic activities. Environ. Earth Sci., 67 (4), 1121, 2012.

41. ONGEN A., DOKMECI H., CELIK S.O., SABUDAK T., KAYKIOGLU G., DOKMECI I. Copper and Cadmium
Contents in Ground and Surface Water in Corlu, Turkey. J. Environ. Prot. Ecol., 9 (4), 753, 2008.

42. KANT R. Textile dyeing industry an environmental hazard. Nat. Sci., 4 (1), 22, 2012.

43. WAKAWA R.J., UZAIRU A., KAGBU J.A., BALARABE M.L. Impact assessment of effluent discharge on physicochemical parameters and some heavy metal concentrations in surface water of River Challawa Kano, Nigeria. Afr. J. Pure Appl. Chem., 2 (10), 100, 2008.

44. GATICA E.A., ALMEIDA C.A., MALLEA M.A., DEL CORIGLIANO M.C., GONZÁLEZ P. Water quality assessment, by statistical analysis, on rural and urban areas of Chocancharava River (Río Cuarto), Córdoba, Argentina. Environ. Monit. Assess., 184, 7257, 2012.

45. ABDULWAHID S.J. Water Quality Index of Delizhiyan Springs and Shawrawa River within Soran District, Erbil, Kurdistan region of Iraq. J. App. Environ. Biol. Sci., 3, 40, 2013. 